\title{
Stable Isotope Analysis Reveals That Agricultural Habitat Provides an Important Dietary Component for Nonbreeding Dunlin
}

\section{L'analyse des isotopes stables indique que les milieux agricoles fournissent une portion importante de l'alimentation du Bécasseau variable en période d'hivernage}

\author{
$\underline{\text { Lesley Joan Evans Ogden }}{ }^{1}, \underline{K e i t h ~ A . H o b s o n}^{2}$, David B. Lank $^{3}$, and Shabtai Bittman ${ }^{4}$
}

\begin{abstract}
Although shorebirds spending the winter in temperate areas frequently use estuarine and supratidal (upland) feeding habitats, the relative contribution of each habitat to individual diets has not been directly quantified. We quantified the proportional use that Calidris alpina pacifica (Dunlin) made of estuarine vs. terrestrial farmland resources on the Fraser River Delta, British Columbia, using stable isotope analysis $(\delta 13 \mathrm{C}, \delta 15 \mathrm{~N})$ of blood from 268 Dunlin over four winters, 1997 through 2000 . We tested for individual, age, sex, morphological, seasonal, and weather-related differences in dietary sources. Based on single- $(\delta 13 \mathrm{C})$ and dual-isotope mixing models, the agricultural habitat contributed approximately $38 \%$ of Dunlin diet averaged over four winters, with the balance from intertidal flats. However, there was a wide variation among individuals in the extent of agricultural feeding, ranging from about $1 \%$ to $95 \%$ of diet. Younger birds had a significantly higher terrestrial contribution to diet (43\%) than did adults $(35 \%)$. We estimated that $6 \%$ of adults and $13 \%$ of juveniles were obtaining at least $75 \%$ of their diet from terrestrial sources. The isotope data provided no evidence for sex or overall body size effects on the proportion of diet that is terrestrial in origin. The use of agricultural habitat by Dunlin peaked in early January. Adult Dunlin obtained a greater proportion of their diet terrestrially during periods of lower temperatures and high precipitation, whereas no such relationship existed for juveniles. Seasonal variation in the use of agricultural habitat suggests that it is used more during energetically stressful periods. The terrestrial farmland zone appears to be consistently important as a habitat for juveniles, but for adults it may provide an alternative feeding site used as a buffer against starvation during periods of extreme weather. Loss or reduction of agricultural habitat adjacent to estuaries may negatively impact shorebird fitness, with juveniles disproportionately affected.
\end{abstract}

RÉSUMÉ. Bien que les oiseaux limicoles qui passent l'hiver dans les climats tempérés utilisent fréquemment les milieux d'alimentation estuariens et supralittoraux (terrestres), la contribution relative de chaque habitat à l'alimentation individuelle n'a pas été quantifiée directement. Nous avons quantifié l'utilisation relative des ressources estuariennes avec celles provenant des zones agricoles terrestres du delta du fleuve Fraser, en Colombie-Britannique par Calidris alpina pacifica (Bécasseau variable), à l'aide de l'analyse d'isotopes stables du sang $(\delta 13 \mathrm{C}, \delta 15 \mathrm{~N})$ provenant de 268 Bécasseaux variables au cours de quatre hivers (1997 à 2000). Nous avons testé les différences dans les sources d'alimentation en fonction des individus, de l'âge, du sexe, de la morphologie, des saisons et des conditions météorologiques. Selon des modèles pour un seul isotope $(\delta 13 \mathrm{C})$ ou combinant deux isotopes, le milieu agricole a fourni environ $38 \%$ des ressources alimentaires utilisées par le Bécasseau variable (moyenne calculée sur les quatre

${ }^{1}$ University of British Columbia, ${ }^{2}$ Canadian Wildlife Service, ${ }^{3}$ Simon Fraser University, ${ }^{4}$ Agriculture and Agri-Food Canada

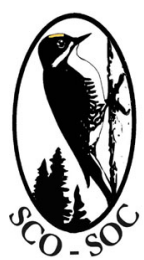

Sponsored by the Society of Canadian Ornithologists and Bird Studies Canada

Parrainée par la Société des onnithologistes du Canada et Études d'oiseaux Canada

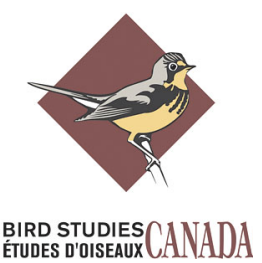


hivers), le reste provenant de la zone intertidale. Toutefois, d'importantes variations ont été notées entre individus, la proportion d'alimentation en milieu agricole représentant de $1 \%$ à $95 \%$ de leur diète. Chez les jeunes oiseaux, l'apport alimentaire terrestre $(43 \%)$ était beaucoup plus élevé que chez les adultes (35\%). Nous avons estimé que chez $6 \%$ des adultes et $13 \%$ des juvéniles obtenaient au moins $75 \%$ de leur régime alimentaire de source terrestre. Les données isotopiques n'ont révélé aucune corrélation entre le sexe et la taille corporelle générale et la proportion du régime alimentaire provenant de source terrestre. L'utilisation de l'habitat agricole par le Bécasseau variable a culminé au début de janvier. Les adultes ont obtenu une plus grande proportion de leur apport alimentaire en milieu terrestre pendant les périodes plus froides avec de fortes précipitations, tandis que cette relation n'était pas observée chez les juvéniles. Les variations saisonnières en matière d'utilisation des habitats agricoles suggèrent qu'ils sont utilisés plus intensivement durant les périodes de stress énergétique. Les zones agricoles terrestres semblent avoir une importance constante comme habitat pour les juvéniles, tandis qu'elles représentent des lieux d'alimentation alternatifs pour les adultes et fournissent un apport alimentaire d'urgence lorsque les conditions météorologiques sont extrêmes. La perte ou la réduction des habitats agricoles adjacents aux estuaires pourraient avoir un effet négatif sur la condition des oiseaux limicoles, les juvéniles étant touchés de façon disproportionnée.

Key Words: carbon-13, nitrogen-15, shorebirds, non-breeding ecology, supratidal habitat use, Calidris alpina pacifica, diet

\section{INTRODUCTION}

Conservation of increasingly threatened coastal habitats has been identified as a key strategy for stemming the population declines currently seen in many species of North American shorebirds (Brown et al. 2001, Donaldson et al. 2001). In shorebirds, most adult mortality takes place during migration or on the wintering grounds, and, given their relatively low reproductive rates, shorebird populations are particularly sensitive to factors that affect adult survivorship during the nonbreeding phase, when shorebirds typically concentrate at high densities (Myers et al. 1987, Evans 1991). Protecting nonbreeding habitats is therefore a critical priority. In some coastal areas, loss of intertidal foraging habitats because of land "reclamation" may be partially offset by agricultural practices that provide waterbird feeding habitat (Colwell and Dodd 1997). Nonbreeding shorebird use of agricultural land in addition to intertidal habitats has been widely documented in western Europe (e.g., Goss-Custard 1969, Fuller and Youngman 1979, Fasola and Ruiz 1996, Masero and Pérez-Hurtado 2001, Smart and Gill 2003) and the United States (White and Harris 1966, Colwell and Dodd 1995, Warnock et al. 1995, Rottenborn 1996, Elphick and Oring 1998, Sanzenbacher and Haig 2002). In the UK, foraging in pastures may be crucial to over-winter survival in at least one species, the Curlew Numenius arquata (Townshend
1981). Knowledge about the importance and use of supratidal habitats such as coastal farmland during the nonbreeding season will augment our ability to assign priorities for conservation.

Within shorebirds, as for many taxa (Conradt et al. 2000), differential habitat use by sex or age, known as habitat segregation, is common during the nonbreeding season. Male and female shorebirds often use different habitat types (Townshend 1981, Puttick 1984, Marra 2000), and habitat segregation by sex is commonly attributed to differences in the structure of the feeding apparatus, particularly bill lengths (Townshend 1981). Habitat segregation by age has been attributed to age-related behavioral, physiological, or morphological differences that result in less efficient feeding by juveniles vs. adults on certain prey types (Marchetti and Price 1989, Hockey et al. 1998) or a competitive advantage of adults over juveniles (Burger 1980, Goss-Custard et al. 1982, Goss-Custard and Le V. dit Durell 1983). Habitat use may also vary seasonally as a result of fluctuating environmental conditions such as weather and day length that can influence prey availability (Goss-Custard 1970, 1984, Evans 1976, Pienkowski 1981), an individual's thermoregulatory costs, (Kelly et al. 2002), and predation vulnerability (Yasué et al. 2003) or "escape performance" (Lank and Ydenberg 2003). Intrinsic differences between males and females, and between juveniles and adults, may mean that 
environmental conditions have disproportionate effects, leading to differential habitat use because of trade-offs between starvation and predation risk (Dierschke 1998, Burns and Ydenberg 2002). Habitat segregation by age or sex can have implications for population demography if there is a disproportionate loss of particular habitat types.

In the Fraser Delta, British Columbia, Canada, prior studies have reported that nonbreeding Dunlin (Calidris alpina pacifica) and other shorebird species use coastal farmland for roosting and feeding (Butler 1999, Shepherd 2001), although the estuarine intertidal flat of the Fraser Delta has been assumed to be their primary feeding habitat. We predicted finding sex and age differences in the proportional dietary contribution of these adjacent habitats to Dunlin mediated by intrinsic sex- and age-related differences as well as their interaction with environmental conditions and seasonal factors. Male and female Dunlin differ substantially in bill morphology and body size. Although there is an overlap of 30-59\% (MacLean and Holmes 1971), females have longer bills, on average, than males (Warnock and Gill 1996). Estuarine intertidal invertebrates such as small annelids burrow deeper into the substrate under certain conditions such as heavy rainfall (Shepherd 2001), whereas the opposite occurs with terrestrial invertebrates (Colwell and Dodd 1997). We predicted an overall increase in the use of terrestrial habitat during periods of heavy rain, but, because deeper intertidal prey would be less available to males than to the longer-billed female Dunlin under such conditions, we predicted an overall male bias in terrestrial feeding.

Compared with older birds, shorebirds in their first winter of life are less experienced at foraging, competing with conspecifics, and avoiding predators (Marchetti and Price 1989). Shorebirds are thought to feed in alternative habitats when they cannot fulfill their energy requirements on the intertidal alone (Smart and Gill 2003). For Dunlin, we expected colder conditions to increase energy demands and starvation risk, and predicted an overall increase in field feeding during lower temperatures and higher wind speeds. Juvenile shorebirds often forage in habitats higher in predation risk than do adults (Cresswell 1994, Warnock 1994, Dierschke 1998), probably because they face a greater risk of starvation than adults. Therefore, we predicted that juveniles would be more likely than adults to feed in the terrestrial zone, which has been shown previously to be a riskier habitat in terms of predation (Shepherd 2001).

Although Dunlin spend proportionally more time foraging on intertidal flats than in fields (Shepherd 2001), the relative precedence of estuarine vs. terrestrial food in the diets of Dunlin has not previously been quantified. We used stable isotope analysis as a tool to determine the relative dietary importance of agricultural habitat to Dunlin. This approach was ideal for our study because marine and terrestrial food webs are isotopically distinct. We investigated individual, age, sex, seasonal, and weather-related variation in the extent of terrestrial vs. estuarine feeding. This research was part of a broader study aimed at elucidating the importance of farmland to shorebirds wintering in the Fraser Delta (Evans Ogden 2002). There is increasing development pressure on traditional agriculture in this region. In particular, the loss of open soil fields to the construction of industrial greenhouses has seen nearly $2 \%$ of the delta's agricultural land reserve converted to greenhouses since 1996. This study therefore contributes knowledge valuable to habitat conservation planning for nonbreeding shorebirds.

\section{METHODS}

\section{Study area}

As seen in Fig. 1, the intertidal flats of the Fraser Delta $\left(49^{\circ} 10^{\prime} \mathrm{N}, 123^{\circ} 05^{\prime} \mathrm{W}\right)$, the largest estuary on Canada's west coast, provide habitat for internationally significant numbers of migrating and overwintering shorebirds, waterfowl, and raptors (Butler and Campbell 1987). Dunlin are the most numerous shorebird species overwintering in the delta, with an average winter population size of 30,000 (Butler 1994). Dunlin begin to arrive in the delta as early as July, but most of them arrive at the beginning of October (Evans Ogden 2002) and are thereafter highly site-faithful residents until their departure in April (Shepherd 2001). The delta consists of approximately $257 \mathrm{~km}^{2}$ of intertidal flat adjacent to approximately $127 \mathrm{~km}^{2}$ of land farmed since the late $1800 \mathrm{~s}$, when natural salt marshes were diked and converted to agricultural use. Farmland is the largest component $(51 \%)$ of the terrestrial zone available to Dunlin in the delta (Butler and Campbell 1987). In winter, the farmland habitat consists of a mosaic of fields, including bare earth 
with or without crop stubble; cover crops such as winter wheat; perennial grasses; winter vegetable crops such as cabbage; and berry crops. The delta has a semidiurnal mixed tidal regime, and tide levels in part drive the timing of use of estuarine vs. adjacent agricultural habitats. The terrestrial habitat is used particularly during high tides, which in winter can inundate the entire surface area of intertidal flat. However, a radio telemetry study recently elucidated extensive nocturnal foraging activity in fields during winter (Shepherd and Lank 2004), when tides are significantly lower than during the day, thus suggesting that abiotic and/or biotic factors other than tidal variation are also involved.

\section{Bird capture and sampling}

Two hundred and eighty-six Dunlin were captured between October and April over the winters of 1997-1998 through 1999-2000, and in November 2000, using mistnets and a floating clap net (L. J. Evans Ogden, unpublished data) placed around the Fraser Delta (Fig. 1). In 1997-1998, birds were captured at night in agricultural fields adjacent to the coastal intertidal flats. However, low densities of Dunlin in these fields resulted in low capture success and a small sample size, and in 1998-1999, birds were captured in fields and at two locations on the intertidal flats of Boundary Bay $\left(49^{\circ} 00^{\prime} \mathrm{N}\right.$, $123^{\circ} 0$ ' $\left.\mathrm{W}\right)$ and Brunswick Point, $\left(49^{\circ} 03^{\prime} \mathrm{N}, 123^{\circ}\right.$ 01'W). In 1999-2000, all birds were captured on the intertidal flats at Brunswick Point. Birds were captured within $3 \mathrm{~h}$ of high tide, usually on an ebbing tide, during the hours of darkness, which varied seasonally between 1600 and 0800 PST. We did not conduct a full season of sampling in 2000-2001, but include here Dunlin captured on two dates in November 2000 for which blood samples were taken prior to an experimental study of these individuals in captivity (Evans Ogden et al. 2004).

We measured length of culmen, tarsus, and wing chord; aged birds as juvenile, i.e., in their first year of life, or adult using plumage characteristics (Warnock and Gill 1996); determined mass; and extracted a $300-\mu \mathrm{L}$ blood sample from the brachial vein of each bird. A sufficient volume of blood for isotope analysis was obtained from 268 of the 286 captured birds. Culmen length was measured from bill tip to the margin between the mandible and feathers at the center of the upper mandible. Tarsus was measured from between the second toe to the tarsal-tibia joint, with the leg held so that the tarsus was perpendicular to the tibia. Wing chord was measured as the flattened length of the longest primary feather. We used whole blood, which provided an indication of diet source integrated over a time window of at least $21 \pm 1 \mathrm{~d}$ or two half lives, based on laboratory studies of captive Dunlin to determine turnover times of ${ }^{13} \mathrm{C}$ and ${ }^{15} \mathrm{~N}$ (Evans Ogden et al. 2004). To ensure that all Dunlin would have isotopic signatures indicative of their winter diet and retain no residual signature from their summer breeding grounds, Dunlin captured prior to 24 November were excluded from our analyses.

\section{Isotope methods and analyses}

Stable-isotope analyses of animal tissues and their potential prey is a powerful and well studied means of quantifying relative contributions of isotopically distinct dietary components (Hobson and Wassenaar 1999). The relative contribution of terrestrial vs. marine-derived protein in the diets of birds has been estimated using stable-carbon $\left(\delta^{13} \mathrm{C}\right)$ and nitrogen $\left(\delta^{15} \mathrm{~N}\right)$ isotope ratios, because foodweb components differ significantly and predictably between marine and C-3 terrestrial ecosystems (reviewed by Hobson 1999). The evidence suggests that isotopic incorporation into body tissues does not vary with an organism's age (e.g., Minagawa and Wada 1984), and differences in isotopic discrimination factors, i.e., the isotopic difference between food source and tissues, between individuals are small (e.g., Hobson and Clark 1993), so that individual differences in isotopic values can usually be ascribed to individual differences in diet. Stable isotope analysis provides several benefits in comparison with traditional methods for quantifying diet, such as the analysis of stomach and fecal contents (Cree et al. 1999). In particular, stable isotope analysis (1) provides information for all the individuals sampled, including those with empty stomachs; (2) avoids the bias resulting from the differential digestion of soft- vs. hard-bodied prey; (3) provides information on the foods assimilated, not just ingested; (4) gives information on diet assimilated over a relatively long time window, rather than just the time "snapshot" provided by stomach and fecal analysis; (5) provides long-term information on habitat use without the logistical difficulties of marking and resighting; (6) can be performed using a variety of tissues depending on the time frame of interest; and (7) can be nonlethal. This method is ideally suited to this study, because 
Fig. 1. Agricultural lands in the Fraser River Delta (gray shading). Arrows indicate locations of Dunlin capture and invertebrate sampling. Numbers indicate year of sampling for Dunlin commencing 1997-1998. Letters indicate type of invertebrates sampled: $\mathrm{A}=$ terrestrial invertebrates, $\mathrm{B}=$ estuarine invertebrates.

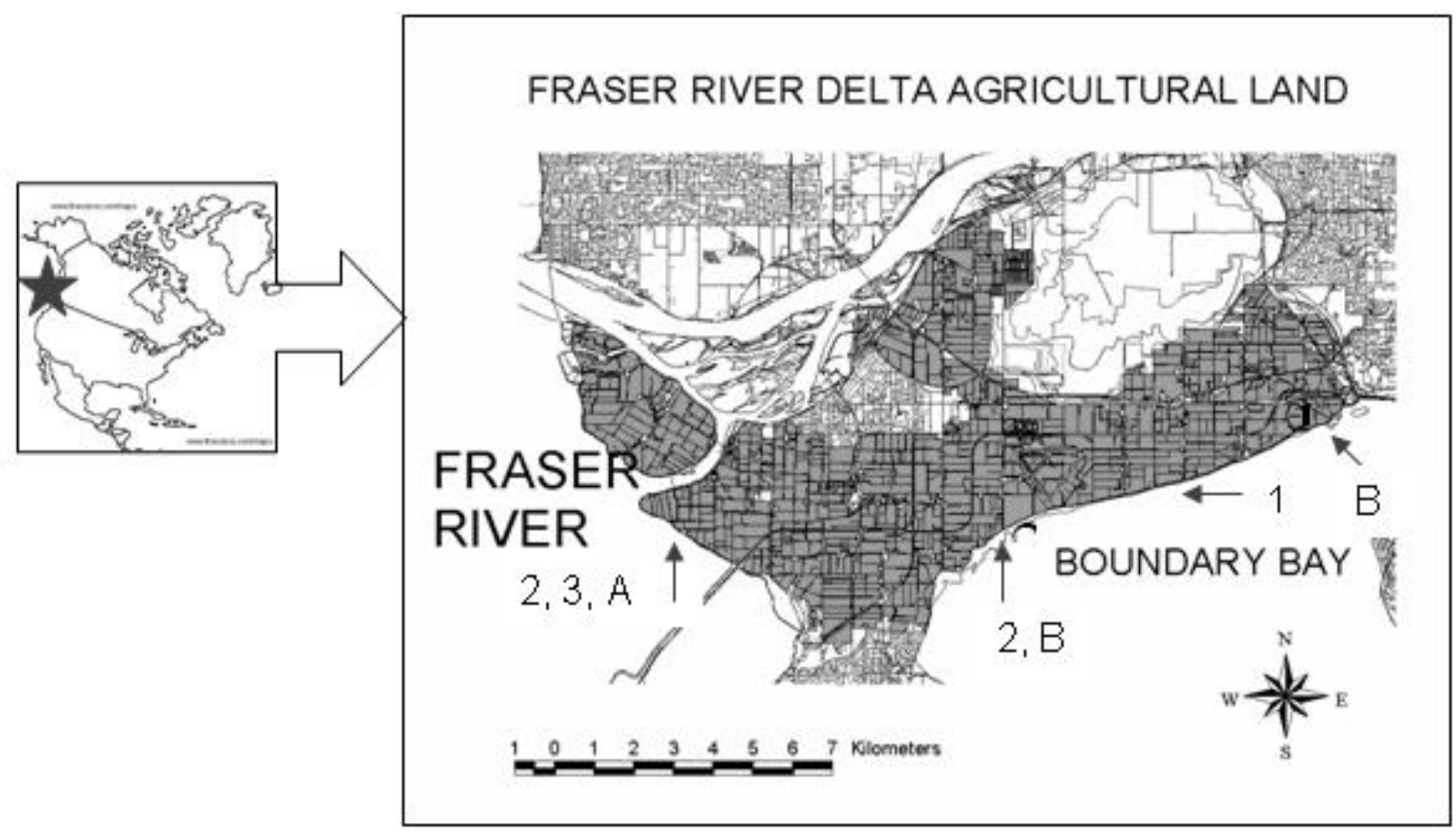

it provides time-integrated insights into winter diet and because many Dunlin prey are soft-bodied organisms (e.g., Warnock and Gill 1996) that are quickly digested and therefore difficult or impossible to detect in dissected stomachs or feces (e.g., Duffy and Jackson 1986). Some previous studies using this technique have raised concerns regarding the metabolic routing of nutrients, in that isotope analysis of tissues provides relatively good estimates of protein pathways but not of carbohydrate or lipid pathways (Hobson and Bairlein 2003). However this is not a major concern in our study because Dunlin eat almost exclusively protein-rich invertebrates.
Dunlin were consistently observed flying into and feeding in terrestrial habitats during diurnal and nocturnal habitat surveys at high tide (Evans Ogden 2002), and the few alternate terrestrial habitats available are not recognized as frequently used by Dunlin, e.g., suburban and industrial areas, wooded areas, a golf course, and a bog (Butler and Campbell 1987, Shepherd 2001). Thus, we assumed that terrestrial signatures reflected diet assimilated via feeding in agricultural fields. Our isotopic model was based, then, on delineating protein inputs from a terrestrial C 3 ecosystem vs. estuarine mudflats that experienced mixed marine and freshwater inputs. Using our data, we were not able to distinguish between the different types of agricultural fields in which birds fed, but data on selection of field type are presented elsewhere (Evans Ogden 2002). 
To delineate the isotopic end points of the local system, i.e., the terrestrial and estuarine ecosystems used by Dunlin, we obtained intertidal invertebrate samples from P. Shepherd, who collected samples along transects at Boundary Bay and Mud Bay in February 1996. Terrestrial invertebrates were opportunistically collected along transects within fields adjacent to Brunswick Point (Fig. 1) in March 2002. Our collection included major food items known to be used locally by Dunlin (Shepherd 2001, Evans Ogden 2002; E. H. McEwan and K. Fry, unpublished data) to confirm isotopic signatures for these habitats. Whole-organism invertebrate samples were stored frozen and later freeze-dried prior to laboratory analysis. Diet-blood isotopic discrimination values of $+1.3 \%$ ofor $\delta^{13} \mathrm{C}$ values and $+2.9 \%$ for $\delta^{15} \mathrm{~N}$ values were applied to dietary endpoint values based on those established for Dunlin (Evans Ogden et al. 2004). Because Dunlin are dietary generalists, we may not have captured the full isotopic range of their potential prey. To address this concern and for comparative purposes, we also collected tissue samples in April 1999 from avian species that were consumers in exclusively marine and exclusively terrestrial habitats, i.e., whitewinged scoter (Melanittafusca) and American robin (Turdus migratorius), respectively. Weather data for Vancouver International Airport, situated on the coast of the same delta approximately $15 \mathrm{~km}$ north of our study area, were obtained from Environment Canada.

Laboratory analyses were performed at the University of Saskatchewan in Saskatoon. Prior to isotopic analysis, freeze-dried samples were ground to a fine powder in an analytical mill. Stable-carbon and nitrogen isotope assays were performed on 1mg subsamples of homogenized materials by loading into tin cups and combusting at $1800^{\circ} \mathrm{C}$ in a Robo-Prep elemental analyzer (Europa Scientific, Crewe, UK). The resultant $\mathrm{CO}_{2}$ and $\mathrm{N}_{2}$ gases were analyzed using an interfaced Europa 20:20 continuous-flow isotope ratio mass spectrometer (Europa Scientific, Crewe, UK), with every five unknowns separated by two laboratory standards. Stable isotope abundances were expressed in $\delta$ notation as the deviation from standards in parts per thousand (\%o) according to the following equation:

$$
\delta \mathrm{X}=\left[\left(\mathrm{R}_{\text {sample }} / \mathrm{R}_{\text {standard }}\right)-1\right] \times 1000
$$

where $X$ is ${ }^{13} \mathrm{C}$ or ${ }^{15} \mathrm{~N}$ and $R$ is the corresponding ratio ${ }^{13} \mathrm{C} /{ }^{12} \mathrm{C}$ or ${ }^{15} \mathrm{~N} /{ }^{14} \mathrm{~N}$. The $R_{\text {standard }}$ values were the PeeDee Belemnite for ${ }^{13} \mathrm{C}$ and atmospheric $\mathrm{N}_{2}$ for ${ }^{15} \mathrm{~N}$. Replicate measurements of internal laboratory standards (albumen) indicate measurement errors of $\pm 0.1 \%$ and $\pm 0.3 \%$ o for stable-carbon and nitrogen isotope measurements, respectively.

\section{Statistical analyses}

A k-Nearest Neighbor randomization test (Rosing et al. 1998) was used to determine whether end-point species were significantly separated in isotope space. This test treats $\delta^{13} \mathrm{C}$ and $\delta^{15} \mathrm{~N}$ values as spatial data. It calculates the probability that two observed samples are derived from the same population compared with the probability that samples with the same values were generated at random. We used 10,000 randomizations of the data to calculate probabilities. Using this approach confirmed that end points were bivariately and significantly different from each other $(P<0.00001)$. We then used both a dual-isotope mixing model (Phillips and Gregg 2001) and a single-isotope $\delta^{13} \mathrm{C}$ linear model to determine the relative proportion of each ecosystem, i.e., estuarine vs. terrestrial, in the Dunlin diet. We compare the results of these two approaches. We reasoned that $\delta^{13} \mathrm{C}$ values might provide a more robust indicator of estuarine vs. farmland use because nitrogen-based fertilizers have likely been used on the agricultural land (e.g., Macko and Ostrom 1994). We express our results as the proportion of diet derived from terrestrial sources. We calculated the mean proportional values for each sample group separately by capture site and year.

As recommended by Ben-David and Schell (2001), we used mixing models only to provide an index of proportional use and performed subsequent statistical analyses using $\delta^{13} \mathrm{C}$ and model residuals as the best indicator of estuarine vs. terrestrial diet source. We applied an inverse absolute value transformation to improve normality for $\delta^{13} \mathrm{C}$ values. To investigate site and temporal, i.e., seasonal and yearly, trends in our data, we used a 
general linear PROC MIXED model, maximum likelihood method (SAS Institute 2000), with (| $\delta^{13} \mathrm{C}^{-1}$ ) as the dependent variable and the date, capture site, and year as factors. We then used residuals from this model to correct for these effects in a second model testing for age, skeletal size as a proxy for sex, morphological differences, and environmental factors. It was not possible to test directly for year effects independent of site effects in our data, because not all sites were investigated in all years. Therefore, we tested for differences between all possible year-site combinations.

Age was entered into the models scored as a dummy variable $(0=$ juvenile or $1=$ adult $)$. To obtain generalized measures of structural body size independent of mass as a proxy for sex, a principal components analysis was performed with data on culmen length, flattened wing chord, and tarsus length. We then used the broken stick model (Jackson 1993) to determine how many principal components could be meaningfully interpreted. Only the first principal component was interpretable based on this analysis. To examine whether dietary differences were reflected in body condition, a regression of $\delta^{13} \mathrm{C}$ vs. both absolute mass and sizecorrected body mass using residuals from a regression of mass vs. tarsus was performed. To determine how much of the seasonal variation in field feeding could be explained by environmental factors, we used averages for the previous $21 \mathrm{~d}$ for minimum temperature, average rainfall, and average wind speed. Because these variables were intercorrelated, we performed principal components analyses (PCA) to obtain uncorrelated linear combinations of weather variables. The first two principal component scores from the PCA on weather variables were intepretable based on the broken stick model (Jackson 1993). We recognize that, by using 21-d averages for these weather data, we cannot capture Dunlin response to short-term events such as storms. Nevertheless, using this 21$\mathrm{d}$ average for weather provides us with the same time window obtained for diet from the stableisotope signatures, and the findings should represent habitat responses to longer-term weather trends.

\section{RESULTS}

Applying the two-isotope mixing model and the simple linear model based on $\delta^{13} \mathrm{C}$ measurements and our established end points (Table 1), we determined that the proportions of diet attributed to estuarine and terrestrial sources for individual Dunlin ranged from $1 \%$ to $95 \%$. Using the mean isotopic values for Dunlin over the four-winter period (Fig. 2), the proportion of diet attributed to terrestrial sources was $38 \%$, with the identical value obtained from both model calculations. Mean terrestrial proportion of diet for each of the six sample groups of Dunlin, separating years and capture sites and calculated using both models, ranged from $28 \%$ to $64 \%$ (Table 2 ). Dunlin $(n=12)$ from one capture site at Boundary Bay fields in year one were excluded from the model and subsequent analyses because the distribution of their residuals was significantly different from all the others. Values for robins and terrestrial invertebrates were virtually identical (Fig. 2). Values for white-winged scoters and estuarine invertebrates were almost identical in the $\delta^{13} \mathrm{C}$ dimension but differed by nearly $2 \%$ in $\delta^{15} \mathrm{~N}$. As expected, the mean $\delta^{15} \mathrm{~N}$ value for Dunlin was higher than the mean $\delta^{15} \mathrm{~N}$ value for the estuarine invertebrates, one of their major prey, but was less than the $\delta^{15} \mathrm{~N}$ value for white-winged scoters, indicating the higher marine component of the scoter diet.

Stable-carbon isotope values varied seasonally, with signatures most terrestrial in early winter (Fig. 3 ). A cubic equation best described seasonal trends in $\delta^{13} \mathrm{C}$ values and was a better fit for the data in terms of higher $r^{2}$ values and lower $p$ values compared with linear (not significant) and quadratic models. Because the isotopes in our blood samples were integrated over a period of weeks and not hours, our data did not allow exploration of shorterterm day/night differences in field feeding. As seen in Fig. 4, there was high variability in the proportional contribution of terrestrial habitat to diet over the four-winter period (coefficient of variation $=57 \%$ ).

In the principal components analysis (PCA) of weather variables, the first principal component (PC1) eigenvectors accounted for $64 \%$ of the variance, had positive signs for each measure (magnitudes 0.40-0.67), and was interpreted as capturing overall storminess, which occurs principally as warmer rainy vs. cooler drier weather. The second principal component (PC2) accounted for $29 \%$ of the variance, with a positive weighting on minimum temperature and negative weightings on total precipitation and wind speed, reflecting less frequent calm, sunny, drier periods vs. cooler wet ones. In the PCA of morphological parameters, the PC1 eigenvectors accounted for $61 \%$ of the variance 
Fig. 2. Isotopic values (mean $\pm \mathrm{SD} \delta^{15} \mathrm{~N}$ and $\delta^{13} \mathrm{C}$ ) for Dunlin whole blood (all years combined, $n=268$ ), estuarine invertebrates ( $n=21$ samples), and terrestrial invertebrates ( $n=16$ samples). End points illustrated here are raw values and are not corrected by known fractionation factors. Samples of scoter $(n=5)$ and American robin $(n=5)$ are muscle tissue.

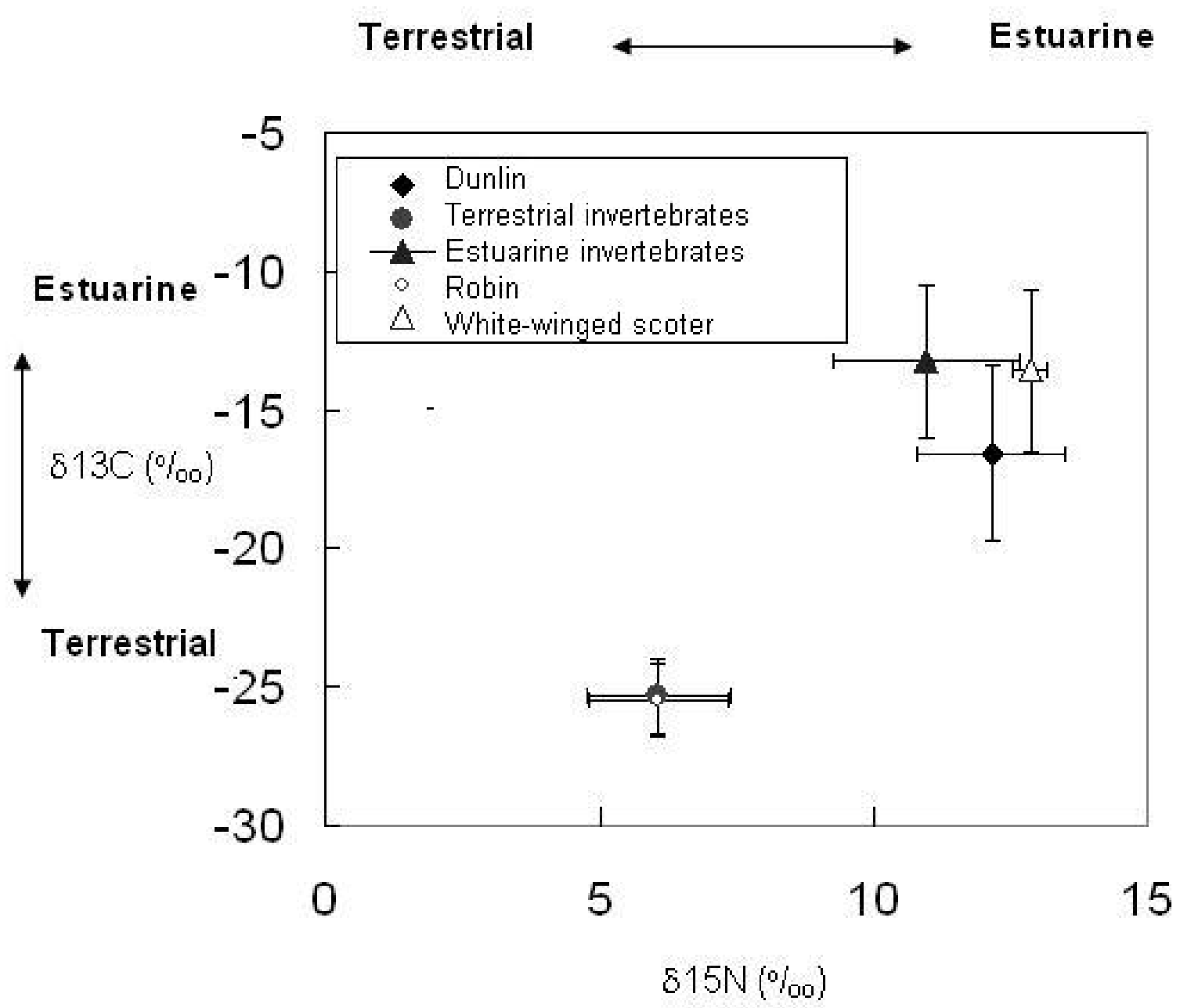

and had positive signs of similar magnitudes for each measure (0.54-0.60), and PC1 was interpreted as a measure of body or skeletal size.

Age was the only variable that explained a significant proportion of the variance in the multivariate model of isotope compositions, and no other morphometric or environmental variable improved a fit from a univariate model including age $\left(F_{1,246}=5.05, P=0.026\right)$. Neither of the PCA scores for weather was a significant main factor in the model, although the interaction PC2-weather, $i$. e., calm, warm, and dry vs. cool and wet, and age was significant $(P<0.05)$ in a model that incorporated all the factors and their interactions with age. No other interactions with age were significant. Further testing revealed a weak but significant inverse relationship between fieldfeeding and temperature for adult Dunlin $\left(r^{2}=\right.$ $\left.0.034, F_{1,154}=5.45, P=0.021\right)$, but not for juveniles 
Table 1. Isotopic values for estuarine and terrestrial invertebrate samples of Dunlin prey species.

\begin{tabular}{|c|c|c|c|c|c|c|}
\hline \multirow[b]{2}{*}{ Location } & \multirow[b]{2}{*}{ Species sampled } & \multirow[b]{2}{*}{$N$} & \multicolumn{2}{|c|}{$\delta^{15} \mathrm{~N}(\% 0)$} & \multicolumn{2}{|c|}{$\delta^{13} \mathrm{C}(\% \circ)$} \\
\hline & & & Mean & SD & Mean & SD \\
\hline \multirow[t]{4}{*}{ Estuarine } & $\begin{array}{l}\text { Clam (Macoma sp., Mya } \\
\text { sp.) }\end{array}$ & $4^{\dagger}$ & 9.75 & $(2.73)$ & -17.21 & $(3.53)$ \\
\hline & Snails (Bittium sp.) & 8 & 9.90 & $(1.50)$ & -11.00 & $(1.67)$ \\
\hline & Polychaete annelids & $9^{\ddagger}$ & 12.38 & $(0.79)$ & -15.19 & $(1.88)$ \\
\hline & Total & 21 & 10.94 & $(1.95)$ & -13.98 & $(3.25)$ \\
\hline \multirow[t]{3}{*}{ Terrestrial } & Earthworm (Lumbricus sp.) & 13 & 6.12 & 1.36 & -24.94 & $(1.01)$ \\
\hline & $\begin{array}{l}\text { Insects (Coleoptera: } \\
\text { Carabidae; } \\
\text { Diptera: Cyclorrhapha and } \\
\text { Tipulidae) }\end{array}$ & $3^{\S}$ & 5.76 & $(0.81)$ & -27.18 & $(0.89)$ \\
\hline & Total & 16 & 6.05 & $(1.26)$ & -25.36 & (1.31) \\
\hline
\end{tabular}

†Each sample contained three individuals (i.e., 12 in total).

* Each sample contained >50 individuals, with exact total not counted.

${ }^{\S}$ Each sample contained five individuals.

$\left(r^{2}=0.0002, F_{1,90}=0.02, P=0.90\right)$ (Fig. 5). A significant positive relationship was found between precipitation and field-feeding for adults $\left(r^{2}=0.10\right.$, $\left.F_{1.174}=20.43, P<0.0001\right)$, but not for juveniles $\left(r^{2}\right.$ $\left.=0.19, F_{1,18}=4.21, P=0.06\right)($ Fig. 6$)$, which may be explained by the smaller sample size of the juveniles.

\section{DISCUSSION}

For most Dunlin, the majority of the winter diet was derived from intertidal flats, but more than a third was obtained from terrestrial habitat. This is comparable with a population of Redshanks wintering in southwestern Spain, where individuals obtained a mean of $23 \%$ of their total daily energy requirement from feeding in supratidal salinas or anthropogenic salt pans during the winter, and $82 \%$ during premigration (Masero and Pérez-Hurtado 2001). Interestingly, we found wide variability in the extent to which individuals fed in fields, ranging from little or no use to very high use (up to 95 $\pm 22 \%$ ). These extreme intraspecific differences in behavioral strategies have been found in other studies (Warnock et al. 1995, Shepherd 2001), and merit further study. Seasonal variation in the use of terrestrial habitat suggests that it may be used as a supplementary resource during energetically stressful periods. Nevertheless, the extreme individual variation suggests that fields are the primary foraging habitat for some birds. This is consistent with observations of small numbers of Dunlin seen feeding in fields even at low tide (L. J. Evans Ogden, personal observation), when the majority of Dunlin were foraging on the large areas of exposed intertidal flat. The existence of "field specialists" within a population of Curlew wintering on an estuary was also reported by Townshend (1981).

\section{Seasonal patterns}

Although terrestrial habitat was a dietary contributor throughout the winter, the proportion of Dunlin diet from fields shifted seasonally. Field contribution to diet rose during autumn, peaked in 
Table 2. Proportions of Dunlin diet from terrestrial and estuarine sources as calculated with the two-isotope and single-isotope mixing models.

\begin{tabular}{|c|c|c|c|c|c|c|c|c|c|}
\hline $\begin{array}{l}\text { Year and } \\
\text { capture site }\end{array}$ & Sample size & $\begin{array}{l}\text { Mean } \delta^{13} \mathrm{C} \\
\text { value }(\% o)\end{array}$ & $\begin{array}{l}\text { Mean } \delta^{15} \mathrm{~N} \\
\text { value }(\% o)\end{array}$ & $\begin{array}{c}\text { Terrestrial \% } \\
\text { of diet } \dagger\end{array}$ & $\begin{array}{l}95 \% \text { Conf- } \\
\text { idence int- } \\
\text { ervals } \dagger\end{array}$ & $\begin{array}{c}\text { Terrestrial \% } \\
\text { of diet } \ddagger\end{array}$ & $\begin{array}{c}\text { Standard } \\
\text { deviation } \ddagger\end{array}$ & $\begin{array}{l}\text { Minimum } \\
\text { terrestrial \% } \\
\text { of diet } \$\end{array}$ & $\begin{array}{c}\text { Maximum } \\
\text { terrestrial \% } \\
\text { of diet } \$\end{array}$ \\
\hline $\begin{array}{l}\text { 2000-2001 } \\
\text { BP shore }\end{array}$ & 31 & -15.32 & 12.32 & 0.28 & $0.17-0.40$ & 0.30 & 2.38 & 0.01 & 0.69 \\
\hline $\begin{array}{l}\text { 1999-2000 } \\
\text { BP shore }\end{array}$ & 181 & -16.30 & 11.85 & 0.36 & $0.26-0.46$ & 0.37 & 0.23 & 0.06 & 0.95 \\
\hline $\begin{array}{l}\text { 1998-1999 } \\
\text { BB shore }\end{array}$ & 8 & -19.02 & 12.56 & 0.59 & $0.42-0.77$ & 0.54 & 0.20 & 0.28 & 0.89 \\
\hline $\begin{array}{l}\text { 1998-1999 } \\
\text { BB field }\end{array}$ & 25 & -16.94 & 13.70 & 0.41 & $0.32-0.50$ & 0.38 & 0.10 & 0.23 & 0.68 \\
\hline $\begin{array}{l}\text { 1998-1999 } \\
\text { BP field }\end{array}$ & 11 & -18.05 & 11.78 & 0.51 & $0.42-0.60$ & 0.50 & 0.16 & 0.10 & 0.78 \\
\hline $\begin{array}{l}\text { 1997-1998 } \\
\text { BB field }\end{array}$ & 12 & $-19.67^{\S}$ & 12.62 & 0.64 & $0.51-0.77$ & 0.58 & 0.17 & 0.35 & 0.87 \\
\hline $\begin{array}{l}\text { Average } \\
1997-2000\end{array}$ & 268 & -16.54 & 12.13 & 0.38 & $0.29-0.47$ & 0.38 & 0.22 & 0.01 & 0.95 \\
\hline
\end{tabular}

${ }^{\dagger}$ Single-isotope $\left(\delta^{13} \mathrm{C}\right)$ model.

tDual-isotope model.

${ }^{\S}$ Significantly different $(P<0.05)$ from all other year-location groups.

early winter, and declined through the remainder of the season (Fig. 3). Although statistically significant, the $r^{2}$ value was low (0.09), and thus the overall effect of season was relatively small. A similar seasonal pattern of increased field feeding during midwinter was found for Oystercatchers in Scotland by Heppleston (1971), and fields were used only in mid-winter by Oystercatchers on the Exe Estuary in Devon (Goss Custard and Le V. dit Durell 1983). Previous studies suggest that field usage is biased toward hours of darkness (Shepherd 2001), and thus one explanation for the seasonal trend is that fields are used more when day length is shorter. Our data suggest that food availability, energetic condition, and/or predation risk are nonmutually exclusive explanations for seasonal differences in why birds feed in fields. The Fraser Delta supports a large number of overwintering raptors, most of which forage diurnally in the terrestrial zone. Perceived risk of predation is an important component in habitat use decisions for Dunlin wintering in the Fraser Delta, as indicated by the energetically costly over-ocean flock flying behavior adopted to avoid terrestrially hunting predators during daytime high tides (Dekker 1998). Nevetheless, because we did not quantify food availability, energetic condition, or predation risk, we are unable to test these hypotheses as explanations for our weak seasonal trends.

\section{Sex differences}

Neither overall body or skeletal size nor absolute culmen length, which are the best indicators of sex during the nonbreeding season, were significantly related to diet source. Our results therefore failed to support the prediction that birds with relatively short bills feed disproportionately more in terrestrial habitat. In least and western sandpipers Calidris minutilla and C. mauri, the ability to evade predators via escape flight differs by sex because of sexrelated differences in wing shape and wing-loading (Burns and Ydenberg 2002). Females, who are larger, have enhanced escape performance compared with males. If female Dunlin possess a 
Fig. 3. Cubic regression fit for date versus predicted relative contribution of terrestrial diet for all Dunlin sampled over four winters. The predictive equation is: $y=0.1070-0.0012 x+0.0000084 x^{2}+0.000000018 x^{3}$, $r^{2}=0.091, P=<0.0001$. The $\mathrm{Y}$-axis represents a transformation of $\delta^{13} \mathrm{C}$ data $\left(\left|\delta^{13} \mathrm{C}\right|^{-1}\right)$ and is an index of relative use of each ecosystem (estuarine versus terrestrial) in Dunlin diet. [ $\underline{\text { See Erratum] }}$

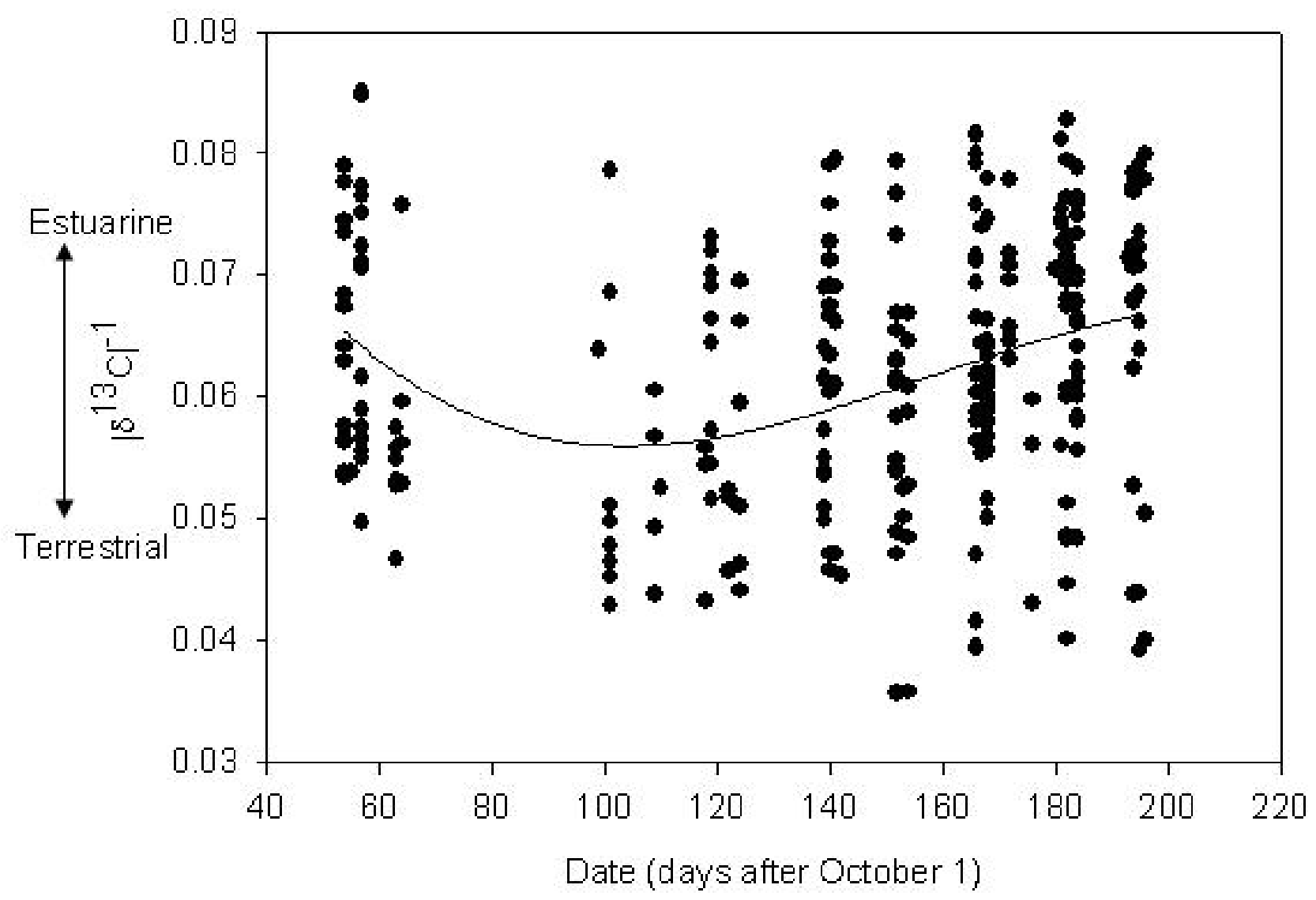

similar superiority in escape performance, we predicted a male-biased predation risk in the terrestrial habitat producing a sex bias toward females. However, our data did not support this prediction. Previous shorebird studies that have looked for sex differences in winter field use have found a male bias (Townshend 1981, Warnock et al. 1995). An additional study of a sample of Dunlin killed by strychnine-poisoned grain in fields of the Central Valley of California indirectly suggested that males feed disproportionately in fields
(Warnock and Schwarzbach 1995).

\section{Age differences}

The most common interpretation of field feeding by shorebirds has been that birds mainly feed in terrestrial habitat when they cannot meet their energy requirements solely from intertidal flat feeding (Goss-Custard 1969, Heppleston 1971). We found age differences in habitat use, with juveniles 
Fig. 4. Frequency distribution of percentage of diet derived from fields for all Dunlin (1997-2000) and by age class (1998-2000). Frequencies represent the proportion of individuals from within that age class. Proportion of diet terrestrial based on two-isotope model calculations.

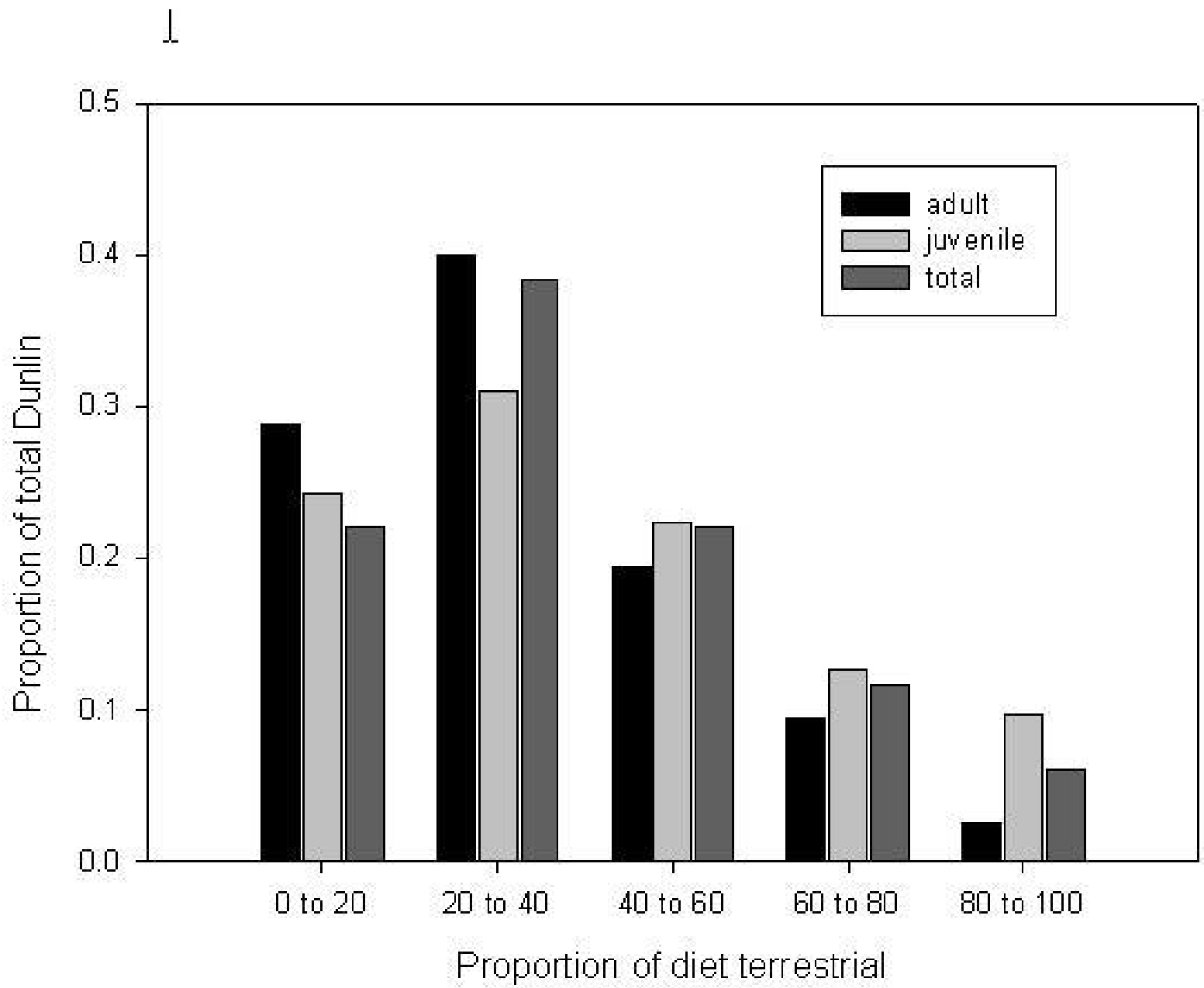

deriving an average of approximately $43.2 \pm 24 \%$ of their diet from terrestrial habitat, as compared with $34.5 \pm 20 \%$ for adults, throughout the winter. This suggests differential starvation-predation risk trade-offs with respect to age classes. In several shorebird species, juveniles appear to be less efficient foragers than adults (Groves 1978, GossCustard and Le V. dit Durell 1987, Marchetti and Price 1989, Hockey et al. 1998, Caldow et al. 1999), and feeding in additional habitats may be crucial for them to make up an energy deficit incurred from insufficient intertidal food. Age-specific differences in foraging ability have been attributed to morphological immaturity, inexperience with feeding techniques that must be learned, different nutritional requirements, and differences in social interactions such as behavioral dominance or reaction to the threat of predation (Marchetti and Price 1989). Physiological factors for age differences in foraging efficiency have been suggested in the western sandpiper $C$. mauri (Stein 2002, Guglielmo and Williams 2003).

Juveniles may forage relatively more successfully 
Fig. 5. Relative use of fields (as represented by transformed $\delta^{13} \mathrm{C}$ values) and mean minimum temperature for previous 21-d period, separated by age class, adults represented by black filled circles, juveniles by open circles. The $\mathrm{Y}$-axis represents a transformation of $\delta^{13} \mathrm{C}$ data $\left(\left|\delta^{13} \mathrm{C}\right|^{-1}\right)$ and is an index of relative use of each ecosystem (estuarine versus terrestrial) in Dunlin diet. The linear regression line of significantly increasing field use with declining temperature is shown in black for adults. The trend line shown for juveniles (dotted line) is for comparison only and is not significant. [ $\underline{\text { See Erratum] }}$

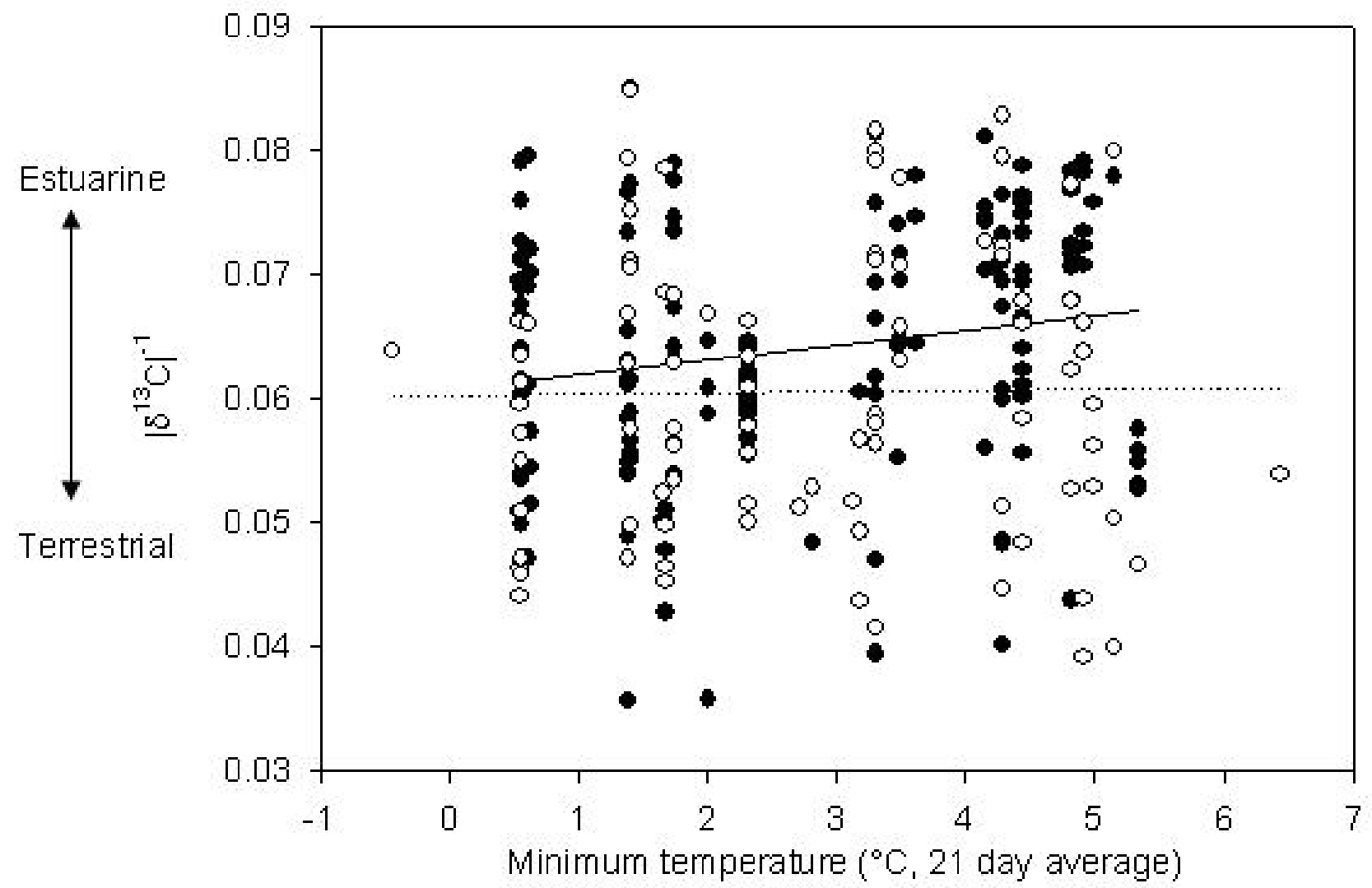

in fields than on the intertidal flats until they gain experience locating and handling marine prey. Our findings of age segregation are consistent with studies of Dunlin on the Dutch Wadden Sea, where juveniles experience higher winter mortality than adults (van der Have et al. 1984), largely attributable to starvation (Pilcher et al. 1974, Evans 1976), perhaps because of the behavioral dominance of adults over juveniles in access to the richest feeding locations (van der Have et al. 1984). Prey types encountered in fields, such as insect larvae (Evans
Ogden 2002), may also be more similar to the prey that juveniles are familiar with from their inland arctic breeding grounds (Holmes 1966).

Cresswell (1994) determined that juvenile Redshank foraged in habitat that maximized their prey intake rate at the expense of increased predation risk as a result of their higher risk of starvation in comparison with adults. Dierschke (1998) determined that, during migratory stopover, juvenile Dunlin fed in habitats that were more profitable in terms of food resources, but of higher 
Fig. 6. Relative use of fields (as represented by transformed $\delta^{13} \mathrm{C}$ values) and mean total precipitation for previous 21-d period, separated by age class, adults represented by black filled circles, juveniles by open circles. The Y-axis represents a transformation of $\delta^{13} \mathrm{C}$ data $\left(\left|\delta^{13} \mathrm{C}\right|^{-1}\right)$ and is an index of relative use of each ecosystem (estuarine versus terrestrial) in Dunlin diet. ASY refers to after-second-year birds, and SY to second-year birds. The linear regression line of significantly increasing field use with increasing precipitation is shown in black for adults. The dotted line shown for juveniles is for comparison only and is not significant. [ See Erratum]

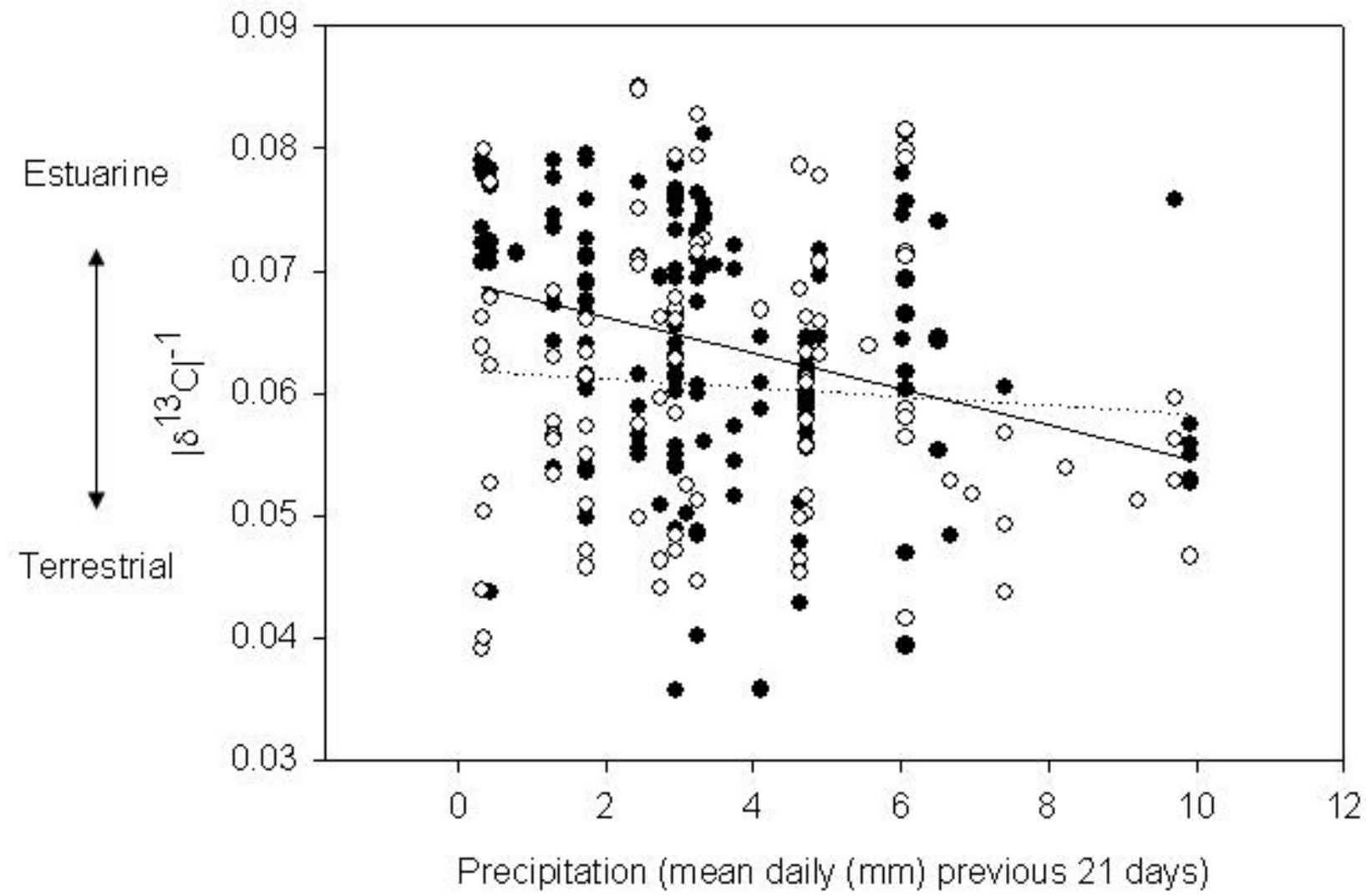

risk of predation, whereas adults chose safer habitats. Similary, Warnock (1990) found that juvenile Dunlin fed disproportionately more than adults in riskier habitats. We did not quantify prey abundance, availability, or profitability in either estuarine or terrestrial habitats, but suspect that juveniles are forced to feed in a riskier habitat because they need to spend longer feeding each day than adults do to balance their energy budgets, thus requiring increased use of fields when intertidal foraging habitat is unavailable. Our findings suggest that, in the absence of fields, juvenile survivorship at this site might decline at a faster rate than that of adults.

\section{Effects of weather}

In our study area, juveniles regularly used terrestrial habitat, but adults used terrestrial habitat to a greater extent during colder periods, when their energy demands and the risk of mud flats and fields freezing 
over were higher. Increased adult use of fields during periods of greater precipitation may be related to the availability of prey, which probably decreases on the intertidal flat while concurrently increasing in fields (Gerstenberg 1979, Heitmeyer et al. 1989, Warnock 1994, Colwell and Dodd 1997). Increased use of fields during winter rains has been reported previously for Dunlin in California (Warnock et al. 1995). Increased field use may also result from an overall increase in time spent feeding during rain (Kelly and Weathers 2002). In Scotland, Heppleston (1971) determined that, under severe weather conditions, juvenile oystercatchers (Haematopus ostralegus occidentalis), feeding at slightly lower rates than adults, were unable to compensate for the food deficit incurred, resulting in higher mortality. Our data suggest that the terrestrial habitat provides an important buffer against starvation for adult Dunlin, especially during periods of extreme weather. With models of global climate change predicting increasingly severe weather extremes such as exceptionally low temperatures and more frequent intense precipitation events (Easterling et al. 2000), terrestrial habitats adjacent to estuaries may become increasingly important for wintering shorebird populations.

\section{CONCLUSION}

Given its close proximity to Vancouver, one of the fastest growing cities in North America, the Fraser Delta will almost certainly face increasing development pressure on it terrestrial landscape in coming decades. Loss of farmland as a result of the expansion of greenhouse agriculture and urban development may adversely affect the fitness of nonbreeding Dunlin, particularly juveniles. Models developed for Oystercatchers in the UK predict that shorebirds in estuaries lacking adjacent agricultural fields have a higher winter mortality rate than do those in estuaries with fields (Stillman et al. 2001). The Fraser Delta is, in fact, the northernmost site in which significant numbers $(>10,000)$ of Dunlin overwinter (Butler and Campbell 1987), and adjacent farmland may be contributing substantially to the estuary's ability to support such a large population. Factors that reduce the availability or profitability of intertidal foraging areas for shorebirds, such as intensive invertebrate harvesting (Piersma et al. 2001), the spread of exotic vegetation such as Spartina spp. (Goss-Custard and Moser 1988), and rising sea levels (Stillman et al. 2000) may increase the future importance of fields and other supratidal lands as buffer habitats (Masero 2003). Our results suggest that proactive protection of such habitats will contribute to the long-term stability of shorebird populations. Ideally, effective habitat conservation strategies for shorebirds will protect coastal farmland in addition to adjacent intertidal habitats.

Responses to this article can be read online at: http://www.ace-eco.org/voll/iss 1/art3/responses/

\section{Acknowledgments:}

Thanks to research assistants Christine Croton, David Vockeroth, and Cory Williams and to Rene and Owain McKibbin and many other field volunteers. We are grateful to the many landowners who permitted access to their farmland. KAH and Patricia Healey (CWS Sask) performed the laboratory analyses. Thanks to Donald Phillips, Merav Ben-David, Mark Drever, Carl Schwarz, and Don Jackson for analytical advice and statistical assistance. Silke Nebel, Fred Cooke, Bob Elner, Bo Söderström, Mark-André Villard, Nils Warnock, and several anonymous reviewers provided helpful comments on earlier drafts of this manuscript. Pippa Shepherd kindly provided estuarine invertebrate samples. This research was supported by funding to KAH by the Canadian Wildlife Service and to LJEO from Agriculture and Agri-Food Canada (Matching Investment Initiative), the National Sciences and Engineering Research Council of Canada, a Wildlife Habitat Canada Ph. D. scholarship, Environment Canada Science Horizons, Simon Fraser University, the Delta Farmland and Wildlife Trust, an American Museum of Natural History Chapman Memorial Award, an American Ornithologists' Union Carnes Award, the Boundary Bay Conservation Committee, the Pacific Field Corn Association, the Canadian Wildlife Service Pacific Coast Joint Venture, a Cooper Ornithologists' Union Mewaldt-King Award, the Government of British Columbia First Job in Science and Technology program, a John K. Cooper Foundation Research Award, and a Sigma-Xi Scientific Research Society Grant-in-Aid of Research. 


\section{LITERATURE CITED}

Ben-David, M., and D. M. Schell. 2001. Mixing models in analyses of diet using multiple stable isotopes: a response. Oecologia 127:180-184.

Brown, S., C. Hickey, B. Harrington, and R. Gill. 2001. United States shorebird conservation plan. Second edition. Manomet Center for Conservation Science, Manomet, Massachusetts, USA.

Burger, J. 1980. Age differences in foraging Blacknecked Stilts in Texas. Auk 97:633-636.

Burns, J. G., and R. C. Ydenberg. 2002. The effects of wing loading and gender on the escape flights of least sandpipers (Calidris minutilla) and western sandpipers (Calidris mauri). Behavioral Ecology and Sociobiology 52:128-136.

Butler, R. W. 1994. Distribution and abundance of western sandpipers, Dunlins, and Black-bellied Plovers in the Fraser River estuary. Pages 18-23 in $\mathrm{R}$. W. Butler and $\mathrm{K}$. Vermeer, editors. The abundance and distribution of estuarine birds in the Strait of Georgia, British Columbia. Canadian Wildlife Service Occasional Paper Number 83. Canadian Wildlife Service, Delta, British Columbia, Canada.

Butler, R. W. 1999. Winter abundance and distribution of shorebirds and songbirds on farmlands on the Fraser River Delta, British Columbia, 1989-1991. Canadian Field

Naturalist 113:390-395.

Butler, R. W., and R. W. Campbell. 1987. The birds of the Fraser River delta: populations, ecology and international significance. Canadian Wildlife Service Occasional Paper Number 65. Canadian Wildlife Service, Delta, British Columbia, Canada.

Caldow, R. W. G., J. G. Goss-Custard, R. A. Stillman, S. E. A. Le V. dit Durell, R. Swinfen, and T. Bregnballe. 1999. Individual variation in the competitive ability of interference-prone foragers: the relative importance of foraging efficiency and susceptibility to interference. Journal of Animal Ecology 68:869-878.

Colwell, M. A., and S. L. Dodd. 1995. Waterbird communities and habitat relationships in coastal pastures of northern California. Conservation Biology 9:827-834.
Colwell, M. A., and S. L. Dodd. 1997. Environmental and habitat correlates of pasture use by nonbreeding shorebirds. Condor 99:337-344.

Conradt, L., T. H. Clutton-Brock, and F. E. Guinness. 2000. Sex differences in weather sensitivity can cause habitat segregation: red deer as an example. Animal Behaviour 59:1049-1060.

Cree, A., G. L., Lyon, L. Cartland-Shaw, and C. Tyrrell. 1999. Stable carbon isotope ratios as indicators of marine versus terrestrial inputs to the diets of wild and captive tuatara (Sphenodon punctatus). New Zealand Journal of Zoology 26:243-253.

Cresswell, W. 1994. Age-dependent choice of redshank (Tringa totanus) feeding location: profitability or risk? Journal of Applied Ecology 63:589-600.

Dekker, D. 1998. Over-ocean flocking by Dunlins, Calidris alpina, and the effect of raptor predation at Boundary Bay, British Columbia. Canadian Field Naturalist 112:694-697.

Dierschke, V. 1998. High profit at high risk for juvenile Dunlins Calidris alpina stopping over at Helgoland (German Bight). Ardea 86:59-69.

Donaldson, G. M., C. Hyslop, R. I. G. Morrison, H. L. Dickson, and I. Davidson. 2001. Canadian shorebird conservation plan. Canadian Wildlife Service, Ottawa, Canada.

Duffy, D. C., and S. Jackson. 1986. Diet studies of seabirds: a review of methods. Colonial Waterbirds 9:1-17.

Easterling, D. R., G. A. Meehl, C. Parmesan, S. A. Changnon, T. R. Karl, and L. O. Mearns. 2000. Climate extremes: observations, modeling, and impacts. Science 289:2068-2074.

Elphick, C. S., and L. W. Oring. 1998. Winter management of Californian rice fields for waterbirds. Journal of Applied Ecology 35:95-108.

Evans, P. R. 1976. Energy balance and optimal foraging strategies in shorebirds: some implications for their distributions and movements in the nonbreeding season. Ardea 64:117-139. 
Evans, P. R. 1991. Seasonal and annual patterns of mortality in migratory shorebirds: some conservation implications. Pages 346-359 in C. H. Perrins, J.-D. Lebreton, and G. J. M. Herons, editors. Bird population studies. Oxford University Press, Oxford, England.

Evans Ogden, L. J. 2002. Non-breeding shorebirds in a coastal agricultural landscape: winter habitat use and dietary sources. Dissertation, Simon Fraser University, Burnaby, Bristish Columbia, Canada.

Evans Ogden, L. J., K. A. Hobson, and D. B. Lank. 2004. Blood isotopic $(\delta 13 \mathrm{C}$ and $\delta 15 \mathrm{~N})$ turnover and diet-tissue fractionation factors in captive Dunlin (Calidris alpina pacifica). Auk 121:170-177.

Fasola, M., and X. Ruiz. 1996. The value of rice fields as substitutes for natural wetlands for waterbirds in the Mediterranean region. Colonial Waterbirds 19(Special Publication 1):122-128.

Fuller, R. J., and R. E. Youngman. 1979. The utilization of farmland by Golden Plovers wintering in southern England. Bird Study 26:37-46.

Gerstenberg, R. H. 1979. Habitat utilization by wintering and migrating shorebirds on Humboldt Bay, California. Studies in Avian Biology 2:33-40.

Goss-Custard, J. D. 1969. The winter feeding ecology of the Redshank Tringa totanus. Ibis 111:338-356.

Goss-Custard, J. D. 1970. Feeding dispersion in some overwintering wading birds. Pages 3-35 in J. H. Crook, editor. Social behaviour in birds and mammals. Academic Press, New York, New York, USA.

Goss-Custard, J. D. 1984. Intake rates and food supply in migrating and wintering shorebirds. Pages 233-270 in J. Burger and B. L. Olla, editors. Shorebirds: migration and foraging behaviour. Plenum Press, New York, New York, USA.

Goss-Custard, J. D., and S. E. A. Le V. dit Durell. 1983. Individual and age differences in the feeding ecology of Oystercatchers Haematopus ostralegus wintering on the Exe Estuary, Devon. Ibis 125: $155-171$.

Goss-Custard, J. D., and S. E. A. Le V. dit Durell.
1987. Age-related effects in oystercatchers Haematopus ostralegus, feeding on mussels Mytilus edulis. III. The effect of interference on overall intake rate. Journal of Animal Ecology 56:549-558.

Goss-Custard, J. D., S. E. A. Le V. dit Durell, and B. J. Ens. 1982. Individual differences in aggressiveness and food stealing among wintering Oystercatchers, Haematopus ostralegus L. in winter in northern Scotland. Journal of Animal Ecology 40:651-672.

Goss-Custard, J. D., and M. E. Moser. 1988. Rates of change in the numbers of Dunlin, Calidris alpina, wintering in British estuaries in relation to the spread of Spartina anglica. Journal of Applied Ecology 25:95-109.

Groves, S. 1978. Age-related differences in Ruddy Turnstone foraging and aggressive behavior. Auk 95:95-103.

Guglielmo, C. G., and T. D. Williams. 2003. Phenotypic flexibility of body composition in relation to migratory state, age and sex in the western sandpiper. Physiological and Biochemical Zoology 76:84-98.

Heitmeyer, M. E., D. P. Connely, and R. L. Pederson. 1989. The Central, Imperial and Coachella valleys of California. Pages 475-505 in L. M. Smith, R. L. Pederson, and R. M. Kiminski, editors. Habitat management for migrating and winter waterfowl in North America. Texas Tech University Press, Lubbock, Texas, USA.

Heppleston, P. R. 1971. The feeding ecology of Oystercatchers (Haematopus ostralegus L.) in winter in northern Scotland. Journal of Animal Ecology 40:651-672.

Hobson, K. A. 1999. Tracing origins and migration of wildlife using stable isotopes: a review. Oecologia 120:314-326.

Hobson, K. A., and F. Bairlein. 2003. Isotopic fractionation and turnover in captive Garden Warblers (Sylvia borin): implications for delineating dietary and migratory associations in wild passerines. Canadian Journal of Zoology 81:1630-1635.

Hobson, K. A., and R. G. Clark. 1993. Turnover of ${ }^{13} \mathrm{C}$ in cellular and plasma fractions of blood: 
implications for nondestructive sampling in avian dietary studies. Auk 110:638-641.

Hobson, K. A., and L. I. Wassenaar. 1999. Stable isotope ecology: an introduction. Oecologia 120:312-313.

Hockey, P. A. R., J. K. Turpie, and C. R. Velásquez. 1998. What selective pressures have driven the evolution of deferred northward migration by juvenile shorebirds? Journal of Avian Biology 29:325-330.

Holmes, R. T. 1966. Feeding ecology of the redbacked sandpiper (Calidris alpina) in Arctic Alaska. Ecology 47:32-45.

Jackson, D. A. 1993. Stopping rules in principal components analysis: a comparison of heuristic and statistical approaches. Ecology 74: 2204-2214.

Kelly J. P., and W. W. Weathers. 2002. Effects of feeding time constraints on body mass regulation and energy expenditure in wintering Dunlin (Calidris alpina). Behavioral Ecology 13:766-775.

Kelly, J. P., N. Warnock, G. W. Page, and W. W. Weathers. 2002. Effects of weather on daily body mass regulation in wintering Dunlin. Journal of Experimental Biology 205:109-120.

Lank, D. B., and R. C. Ydenberg. 2003. Death and danger at migratory stopovers: problems with "predation risk." Journal of Avian Biology 34:225-228.

Macko, S. A., and N. E. Ostrom. 1994. Pollution studies using stable isotopes. Pages 45-62 in K. Lajtha and R. H. Michener, editors. Stable isotopes in ecology and environmental science. Blackwell Scientific, Oxford, UK.

MacLean, S. F., and R. T. Holmes. 1971. Bill lengths, wintering areas, and taxonomy of North American Dunlins Calidris alpina. Auk 88: 893-901.

Marchetti, K., and T. Price 1989. Differences in the foraging of juvenile and adult birds: the importance of developmental constraints. Biological Review 64:51-70.

Marra, P. P. 2000. The role of behavioral dominance in structuring patterns of habitat occupancy in a migrant bird during the nonbreeding season. Behavioral Ecology 11:299-308.

Masero, J. A. 2003. Assessing alternative anthropogenic habitats for conserving waterbirds: salinas as buffer areas against the impact of natural habitat loss for shorebirds. Biodiversity and Conservation 12:1157-1173.

Masero, J. A., and A. Pérez-Hurtado. 2001. Importance of the supratidal habitats for maintaining overwintering shorebird populations: how redshanks use tidal mud flats and adjacent saltworks in southern Europe. Condor 103:21-30.

Minagawa, M., and E. Wada. 1984. Stepwise enrichment of ${ }^{15} \mathrm{~N}$ along food chains: further evidence and the relation between $\delta^{15} \mathrm{~N}$ and animal age. Geochimica et Cosmochimica Acta 48:1135-1140.

Myers, J. P., R. I. G. Morrison, P. Z. Antas, B. A. Harrington, T. E. Lovejoy, M. Sallaberry, S. E. Senner, and A. Tarak. 1987. Conservation strategy for migratory species. American Scientist 75:19-26.

Phillips, D. L., and J. W. Gregg. 2001. Uncertainty in source partitioning using stable isotopes. Oecologia 127:171-179.

Pienkowski, M. W. 1981. How foraging plovers cope with environmental effects of invertebrate behaviour and availability. Pages 179-192 in N. V. Jones and W. F. Wolff, editors. Feeding and survival strategies of estuarine organisms. Plenum Press, London, UK.

Piersma, T., A. Koolhaas, A. Dekinga, J. J. Beukema, R. Dekker, and K. Essink. 2001. Longterm indirect effects of mechanical cockle-dredging on intertidal bivalve stocks in the Wadden Sea. Journal of Applied Ecology 38:976-990.

Pilcher, R. E. M., J. V. Beer, and A. W. Cook. 1974. Ten years of intensive late-winter surveys for waterfowl corpses on the north-west shore of the Wash, England. Wildfowl 25:149-154.

Puttick, G. M. 1984. Foraging and activity patterns in wintering shorebirds. Pages 203-232 in J. Burger and B. L. Olla, editors. Shorebirds-migration and foraging behavior. Plenum Press, New York, New York, USA.

Rosing, M. N., M. Ben-David, and R. P. Barry. 
1998. Analysis of stable isotope data: a $k$ nearest neighbours randomization test. Journal of Wildlife Management 62:380-388.

Rottenborn, S. C. 1996. The use of coastal agricultural fields in Virginia as foraging habitat by shorebirds. Wilson Bulletin 108:783-796.

Sanzenbacher, P. M., and S. M. Haig. 2002. Residency and movement patterns of wintering Dunlin in the Willamette Valley of Oregon. Condor 104:271-280.

SAS Institute. 2000. SAS version 8. SAS Institute, Cary, North Carolina, USA.

Shepherd, P. C. F. 2001. Space use, habitat preferences, and time-activity budgets of nonbreeding Dunlin (Calidris alpina pacifica) in the Fraser River, Delta, B.C. Dissertation, Simon Fraser University, Burnaby, British Columbia, Canada.

Shepherd, P. C. F., and D. B. Lank. 2004. Marine and agricultural habitat preferences of Dunlin wintering in British Columbia. Journal of Wildlife Management 68:61-73.

Smart, J., and J. A. Gill. 2003. Non-intertidal habitat use by shorebirds: a reflection of inadequate intertidal resources? Biological Conservation 111:359-369.

Stein, R. W. 2002. Busting a gut: age-related variation and seasonal modulation of digestive tract structure and function in the western sandpiper. Dissertation, Simon Fraser University, Burnaby, British Columbia, Canada.

Stillman, R. A., J. D. Goss-Custard, A. D. West, S.E.A. Le V. dit Durell, R. W. G. Caldow, S. McGrorty, and R. T. Clarke. 2000. Predicting to novel environments: tests and sensitivity of a behaviour-based population model. Journal of Applied Ecology 37:564-588.

Stillman, R. A., J. D. Goss-Custard, A. D. West, S.E.A. Le V. dit Durell, S. McGrorty, R. W. G. Caldow, K. J. Norris, I. G. Johnstone, B. J. Ens, J. van der Meer, and P. Triplet. 2001. Predicting wader mortality and population size under different regimes of shellfishery management. Journal of Applied Ecology 38:857-868.

Townshend, J. D. 1981. The importance of field feeding to the survival of wintering male and female curlews Numenius arquata on the Tees estuary. Pages 261-274 in N. V. Jones and W. J. Wolff, editors. Feeding and survival strategies of estuarine organisms. Plenum Press, New York, New York, USA.

van der Have, T. M., E. Nieboer, and G. C. Boere. 1984. Age-related distribution of Dunlin in the Dutch Wadden Sea. Pages 160-176 in P. R. Evans, J. D. Goss-Custard, and W. G. Hale, editors. Coastal waders and wildfowl in winter. Cambridge University Press, Cambridge, UK.

Warnock, N. D. 1990. Apparent age segregation of Dunlin within Bolinas Lagoon: a preliminary study. Wader Study Group Bulletin 60:27-30.

Warnock, N. D. 1994. Biotic and abiotic factors affecting the distribution and abundance of a wintering population of Dunlin. Dissertation, University of California, Davis, California, USA, and San Diego State University, San Diego, California, USA.

Warnock, N., and R. E. Gill. 1996. Dunlin (Calidris alpina). Birds of North America Number 203. The Academy of Natural Sciences, Philadelphia, and The American Ornithologists' Union, Washington, D.C., USA.

Warnock, N., and S. Schwarzbach. 1995. Incidental kill of Dunlin and Killdeer by strychnine. Journal of Wildlife Diseases 31:566-569.

Warnock, N., G. W. Page, and L. E. Stenzel. 1995. Non-migratory movements of Dunlins on their California wintering grounds. Wilson Bulletin 107:131-139.

White, M., and S. W. Harris. 1966. Winter occurrence, foods and habitat use of Snipe in Northwest California. Journal of Wildlife Management 30:23-34.

Yasué, M., J. L. Quinn, and W. Cresswell. 2003. Multiple effects of weather on the starvation and predation risk trade-off in choice of feeding location in Redshanks. Functional Ecology 17:727-736. 